\title{
Effects of dietary Bacillus amyloliquefaciens supplementation on growth performance, intestinal morphology, inflammatory response, and microbiota of intra-uterine growth retarded weanling piglets
}

Yue Li ${ }^{1}$, Hao Zhang ${ }^{1}$, Weipeng Su', Zhixiong Ying ${ }^{1}$, Yueping Chen ${ }^{1}$, Lili Zhang ${ }^{1}$, Zhaoxin Lu ${ }^{2}$ and Tian Wang ${ }^{1 *}$

\begin{abstract}
Background: The focus of recent research has been directed toward the probiotic potential of Bacillus amyloliquefaciens (BA) on the gut health of animals. However, little is known about BA's effects on piglets with intra-uterine growth retardation (IUGR). Therefore, this study investigated the effects of BA supplementation on the growth performance, intestinal morphology, inflammatory response, and microbiota of IUGR piglets.

Methods: Eighteen litters of newborn piglets were selected at birth, with one normal birth weight (NBW) and two IUGR piglets in each litter (i.e., 18 NBW and 36 IUGR piglets in total). At weaning, the NBW piglet and one of the IUGR piglets were assigned to groups fed a control diet (i.e., the NBW-CON and IUGR-CON groups). The other IUGR piglet was assigned to a group fed the control diet supplemented with $2.0 \mathrm{~g}$ BA per $\mathrm{kg}$ of diet (i.e., IUGR-BA group). The piglets were thus distributed across three groups for a four-week period.

Results: IUGR reduced the growth performance of the IUGR-CON piglets compared with the NBW-CON piglets. It was also associated with decreased villus sizes, increased apoptosis rates, reduced goblet cell numbers, and an imbalance between pro- and anti-inflammatory cytokines in the small intestine. Supplementation with BA improved the average daily weight gain and the feed efficiency of the IUGR-BA group compared with the IUGR-CON group $(P<0.05)$. The IUGR-BA group exhibited increases in the ratio of jejunal villus height to crypt depth, in ileal villus height, and in ileal goblet cell density. They also exhibited decreases in the numbers of jejunal and ileal apoptotic cells and ileal proliferative cells $(P<0.05)$. Supplementation with BA increased interleukin 10 content, but it decreased tumor necrosis factor alpha level in the small intestines of the IUGR-BA piglets $(P<0.05)$. Furthermore, compared with the IUGR-CON piglets, the IUGR-BA piglets had less Escherichia coli in their jejunal digesta, but more Lactobacillus and Bifidobacterium in their ileal digesta $(P<0.05)$.
\end{abstract}

Conclusions: Dietary supplementation with BA improves morphology, decreases inflammatory response, and regulates microbiota in the small intestines of IUGR piglets, which may contribute to improved growth performance during early life.

Keywords: Apoptosis, Bacillus amyloliquefaciens, Immune status, Intra-uterine growth retardation, Microbiota, Piglet, Small intestine

\footnotetext{
* Correspondence: tianwangnjau@163.com

${ }^{1}$ College of Animal Science and Technology, Nanjing Agricultural University,

Nanjing, Jiangsu 210095, China

Full list of author information is available at the end of the article
} 


\section{Background}

Intra-uterine growth retardation (IUGR) is defined as impaired growth and development of the embryo/fetus or its organs during gestation [1]. Approximately 15$20 \%$ of neonatal piglets suffer from IUGR, which has been a significant problem in commercial swine production [2]. Neonates that have experienced IUGR are usually at increased risk of intestinal diseases, and this may be an underlying factor contributing to compromised growth performance and to higher mortality and morbidity during the neonatal period [3-5]. Although the exact etiology of neonatal intestinal diseases remains unclear, prematurity and abnormal bacterial colonization of the gastrointestinal tract, in parallel with loss of commensal microbiota are considered to be risk factors. In general, postnatal colonization of the piglet's intestine begins with the appearance of Escherichia coli, Lactobacilli, and Streptococci [6]. The numbers of those organisms increase rapidly during the first few days, after which Lactobacilli become the predominant group, followed by Enterobacteria, Streptococci, Bacteroides, and Clostridia, in that order [7]. With the introduction of solid feed, anaerobes increase in number and diversity until a stable pattern is established. Lactobacilli remain a predominant part of the bacterial community, after a transient decrease during the weaning transition [8-11]. However, epidemiological and animal studies have indicated that IUGR results in a delay in the establishment of the normal gut bacterial community, with lower numbers of anaerobes, in general, and of Lactobacilli and Bifidobacterium, in particular. This may disturb the colonization resistance of commensal microbiota [12-15]. Moreover, perturbations in the normal pattern of implantation of microbiota may have adverse consequences on digestive and absorptive functions, as well as on the intestinal epithelial barrier [16-18]. This, in turn, may render mucosa susceptible to invasion by luminal bacteria, resulting in the disruption of defense mechanisms, and subsequently leading to intestinal disorders [19].

Numerous reports have suggested that probiotics are beneficial for maintaining intestinal homeostasis and host health [20-22]. In recent decades, several species of Bacillus have been found to promote growth, feed efficiency, and digestive function, and those species are becoming prevalent in swine and poultry feed [23-26]. Among them, Bacillus amyloliquefaciens (BA) has gained more attention, and emerging evidence has identified its health-beneficial properties in the treatment of intestinal disorders, such as diarrhea and inflammation. The likely mechanisms for this are immunomodulation, competitive exclusion of gastrointestinal pathogens, and secretion of the antimicrobial compounds that suppress the growth of harmful bacteria [27, 28]. However, to date, little evidence is available regarding the beneficial effects of BA on IUGR animals. Thus, the objective of the present research was to evaluate the effects of dietary supplementation with BA on the growth performance, intestinal morphology, immune status, and microbiota of IUGR weanling piglets. Pigs are well suited to acting as an animal model for IUGR clinical studies due to their biological similarities to humans, and this study may help in devising preventive strategies for neonatal intestinal diseases of IUGR offspring.

\section{Methods}

\section{Experimental design, diets, and management}

All experiments were conducted in accordance with the guidelines established by the Institutional Animal Care and Use Committee of Nanjing Agricultural University (NJAU-CAST-2016-036). Eighty-two healthy sows with similar parity (second or third) and similar expected farrowing dates (the time between the expected earliest and latest farrowing dates was $4 \mathrm{~d}$ ) were chosen for inclusion in the study. Eighteen litters of between 10 and 13 piglets were selected at birth, and two males in each litter met the selection criteria for IUGR. Newborn piglets [Duroc $\times($ Landrace $\times$ Yorkshire $)]$ with a birth weight $(\mathrm{BW})$ close to the average $\mathrm{BW}$ of the herd [i.e., within 0.5 standard deviations (SD)] were identified as normal BW (NBW), and those with a 2 SD lower BW were defined as IUGR [16, 17, 29]. Two IUGR male piglets $(0.91 \pm 0.05 \mathrm{~kg})$ and one NBW male piglet $(1.50 \pm 0.04 \mathrm{~kg})$ were selected from each litter. All piglets were weaned at $21 \mathrm{~d}$ of age and transferred to the weaner unit. In each litter, the NBW piglet and one of the IUGR piglets were assigned to groups fed the control diet (the NBW-CON and the IUGR-CON group, respectively). The other IUGR piglet was assigned to the group fed the control diet supplemented with $2.0 \mathrm{~g}$ BA per $\mathrm{kg}$ of diet (the IUGR-BA group). The piglets remained in these three groups for a four-week period. Each group consisted of six replicates with three piglets per replicate, making a total of 18 piglets per group (Fig. 1). The strain of BA used in the current study was BA ES-2 $\left(5.4 \times 10^{9}\right.$ colony-forming units per g), a wild-type strain originally isolated from the Scutellaria plant. Prior to this study, we carried out an independent experiment (unpublished) to determine the most appropriate of five possible doses $(0.1 \mathrm{~g}, 0.2 \mathrm{~g}, 0.5 \mathrm{~g}$, $1.0 \mathrm{~g}$, or $2.0 \mathrm{~g}$ per $\mathrm{kg}$ of diet). We found that the optimum effect on the growth performance of NBW piglets was obtained when BA was provided at $1.0 \mathrm{~g}$ and $2.0 \mathrm{~g}$ per $\mathrm{kg}$ of diet. To ensure that the IUGR piglets would receive adequate amounts of BA, a dosage of $2.0 \mathrm{~g}$ per $\mathrm{kg}$ of diet was selected. This is because the feed intake of IUGR piglets is generally lower than that of NBW piglets during the first $4 \mathrm{wk}$ after weaning. The ingredient composition and nutrient content of the diets (see Table 1) were formulated based on the NRC (2012) guidelines [30]. The piglets had 


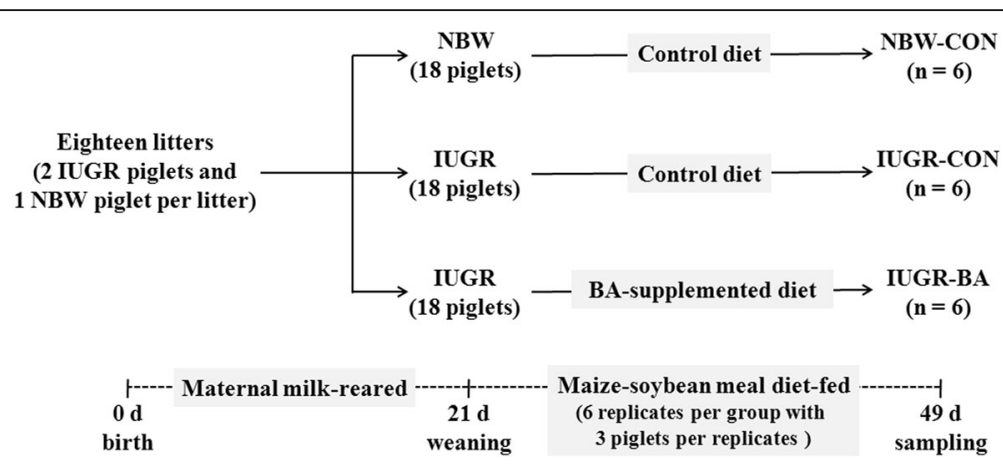

Fig. 1 Schematic representation of the experimental procedures

free access to food and water during the feeding period. Their average daily weight gain (ADG) and average daily feed intake (ADFI) were recorded every week. Feed efficiency (FE) was calculated by dividing ADG by ADFI.

\section{Sample collection}

At the end of the experiment, the piglet with body weight closest to the mean body weight of its replicate was selected (6 piglets per group, making 18 piglets in total). The selected piglets were killed by exsanguination after electrical stunning, following which their entire gastrointestinal tracts were rapidly removed. The small intestine was dissected free of the mesentery and placed on a chilled stainless steel tray. The proximal jejunum and the distal ileum were quickly excised. Their contents were collected, rapidly frozen in liquid nitrogen, and stored at $-80{ }^{\circ} \mathrm{C}$ until analysis. Segments measuring $3 \mathrm{~cm}$ were cut from the jejunum and the ileum and then flushed gently with ice-cold phosphate-buffered saline (PBS, $\mathrm{pH}=7.4$ ). They were then fixed in $4 \%$ fresh, chilled paraformaldehyde solution for histological measurements. Segments of the proximal jejunum and the distal ileum measuring approximately $20 \mathrm{~cm}$ were opened longitudinally, and their contents were flushed with ice-cold PBS. Mucosa was collected by scraping using a sterile glass microscope slide. The mucosa was then rapidly frozen in liquid nitrogen and stored at $80^{\circ} \mathrm{C}$ until analysis.

\section{Intestinal morphology analysis}

After fixation for $24 \mathrm{~h}$, the intestinal samples were dehydrated using a graded series of ethanol (70-100\%) and cleared with xylene, and then the samples were embedded in paraffin. Cross sections of the segments were cut at a thickness of $5 \mu \mathrm{m}$ and stained with hematoxylin and eosin. Villus height (VH) and crypt depth (CD) of fifteen well-oriented villi per segment were measured using a Nikon ECLIPSE 80i light microscope with a computerassisted morphometric system (Nikon Corporation, Tokyo, Japan).

\section{Goblet cell staining}

The samples for goblet cell staining were prepared in accordance with the procedures for the intestinal morphology analysis. The combined Alcian Blue/periodic acid Schiff stain technique was then employed to measure the intestinal goblet cell density [31]. In particular, deparaffinized and rehydrated sections were stained with $1.0 \%$ Alcian Blue solution (Alcian Blue in 3\% acetic acid solution), gently washed in double-distilled $\mathrm{H}_{2} \mathrm{O}$ for $10 \mathrm{~min}$, oxidized in $1.0 \%$ periodic acid solution for $15 \mathrm{~min}$, rinsed again in double-distilled $\mathrm{H}_{2} \mathrm{O}$ for $10 \mathrm{~min}$, and then placed in periodic acid Schiff solution for $30 \mathrm{~min}$. Goblet cells were counted in fifteen well-oriented villi per section, using the Nikon ECLIPSE 80i light microscope (Nikon Corporation, Japan). Goblet cell density was calculated as the goblet cell count divided by the corresponding villus length, averaged and expressed as goblet cell number per $100 \mu \mathrm{m}$ of villus length.

\section{Immunohistochemistry}

Terminal deoxynucleotidyl transferase-mediated deoxyuridine triphosphate nick end labeling (TUNEL) staining was performed to detect the percentage of apoptotic cells in the jejuna and the ilea of piglets. Samples for TUNEL assay were prepared as described for intestinal morphology analysis. In summary, paraformaldehydefixed, paraffin-embedded full-thickness intestinal samples were cut into crosssections $5 \mu \mathrm{m}$ thick, mounted on Superfrost Plus glass slides, deparaffinized, and rehydrated (xylenes, 100\% ethanol, 90\% ethanol, 70\% ethanol, and double-distilled $\mathrm{H}_{2} \mathrm{O}$ ). Following a PBS wash, the slices were incubated with the DNase-free protease $\mathrm{K}$ solution $(20 \mu \mathrm{g} / \mathrm{mL})$ for $30 \mathrm{~min}$ at $25{ }^{\circ} \mathrm{C}$. To deactivate endogenous peroxides, the $\mathrm{H}_{2} \mathrm{O}_{2}$ solution (3\% in PBS) was placed on the slides for $20 \mathrm{~min}$ at $25^{\circ} \mathrm{C}$. After that, the slices were washed in PBS three times and incubated with TUNEL reaction mixture (Beyotime Institute of Biotechnology, Haimen, China) for $60 \mathrm{~min}$ at $37^{\circ} \mathrm{C}$. The slices were rinsed again and incubated with horseradish peroxidase-conjugated streptavidin solution (Beyotime 
Table 1 Composition and nutrient level of the diet (as-fed basis)

\begin{tabular}{|c|c|}
\hline Items $^{\mathrm{a}}$ & Contents \\
\hline \multicolumn{2}{|l|}{ Ingredients, \% } \\
\hline Maize & 62.78 \\
\hline Soybean meal & 15.00 \\
\hline Fermented soybean meal & 7.00 \\
\hline Extruded soybean & 7.00 \\
\hline Soy protein isolate & 1.30 \\
\hline Soybean oil & 2.00 \\
\hline $\mathrm{CaHPO}_{4}$ & 1.80 \\
\hline Limestone & 0.80 \\
\hline Salt & 0.35 \\
\hline L-lysine $\mathrm{HCl}, 78 \%$ & 0.52 \\
\hline L-methionine & 0.13 \\
\hline L-threonine & 0.15 \\
\hline L-isoleucine & 0.10 \\
\hline L-tryptophan & 0.01 \\
\hline L-histidine & 0.01 \\
\hline Calcium propionate, $50 \%$ & 0.05 \\
\hline Premix ${ }^{b}$ & 1.00 \\
\hline Total & 100.00 \\
\hline \multicolumn{2}{|l|}{ Calculated nutrient levels } \\
\hline Digestible energy, Mcal/kg & 3.47 \\
\hline Metabolizable energy, Mcal/kg & 3.30 \\
\hline Crude protein & 20.38 \\
\hline SID lysine & 1.34 \\
\hline SID methionine & 0.40 \\
\hline SID methionine + cystine & 0.72 \\
\hline SID threonine & 0.80 \\
\hline SID tryptophan & 0.35 \\
\hline SID histidine & 0.65 \\
\hline SID isoleucine & 0.70 \\
\hline SID valine & 1.04 \\
\hline Total calcium & 0.82 \\
\hline Available phosphorus & 0.43 \\
\hline \multicolumn{2}{|l|}{ Analyzed nutrient levels } \\
\hline Crude protein & 20.45 \\
\hline Total lysine & 1.53 \\
\hline Total methionine & 0.45 \\
\hline Total methionine + cystine & 0.85 \\
\hline Total threonine & 0.95 \\
\hline Total tryptophan & 0.39 \\
\hline Total histidine & 0.75 \\
\hline Total isoleucine & 0.80 \\
\hline
\end{tabular}

Table 1 Composition and nutrient level of the diet (as-fed basis) (Continued)

\begin{tabular}{ll}
\hline Items $^{\text {a }}$ & Contents \\
\hline Total valine & 1.20 \\
Total calcium & 0.81 \\
Total phosphorus & 0.66
\end{tabular}

${ }^{\mathrm{a}} \mathrm{SID}$ standard ileal digestible

${ }^{b}$ Provide the following per kg complete diet: Vitamin A, 8,000 IU; Vitamin $D_{3}$, 3,000 IU; Vitamin E, 20 IU; Vitamin $\mathrm{K}_{3}, 3 \mathrm{mg}$; Vitamin $\mathrm{B}_{1}, 2 \mathrm{mg}$; Vitamin $\mathrm{B}_{2}$,

$5 \mathrm{mg}$; Vitamin $B_{6}, 7 \mathrm{mg}$; Vitamin $B_{12}, 0.02 \mathrm{mg}$; Niacin, $30 \mathrm{mg}$; Pantothenic acid, $15 \mathrm{mg}$; Folic acid, $0.3 \mathrm{mg}$; Biotin, $0.08 \mathrm{mg}$; Choline chloride, $500 \mathrm{mg}$; Fe (from ferrous sulfate), $110 \mathrm{mg}$; $\mathrm{Cu}$ (from copper sulfate) $7 \mathrm{mg}$; Mn (from manganese sulfate), $5 \mathrm{mg}$; $\mathrm{Zn}$ (from zinc sulfate), $110 \mathrm{mg}$; (from calcium iodate), $0.3 \mathrm{mg}$; $\mathrm{Se}$ (from sodium selenite), $0.3 \mathrm{mg}$

Institute of Biotechnology, China) for $30 \mathrm{~min}$ at $25{ }^{\circ} \mathrm{C}$, and later with Di-amino-benzidine (DAB) chromogenic reagent (Beyotime Institute of Biotechnology, China) for 5 min at $25{ }^{\circ} \mathrm{C}$. The slices were lightly counterstained with hematoxylin (Beyotime Institute of Biotechnology, China), dehydrated with ethanol, and mounted. The tissue sections were observed under the above mentioned Nikon ECLIPSE 80i light microscope (Nikon Corporation, Japan). The percentage of apoptotic cells (brown cells) was calculated by counting at least 200 cells in fifteen random villi per segment.

$\mathrm{Ki}-67$ is a reliable marker for proliferation and mucosal crypt cell proliferation was determined using Ki-67 immunohistochemistry staining [32]. The samples were prepared as described above. The slides were treated with EDTA antigen retrieval for $25 \mathrm{~min}$ in a steamer. After quenching endogenous peroxidase and blocking nonspecific bindings, the slides were incubated with primary antibody (polyclonal rabbit anti-pig antibodies against Ki-67; Abcam, Cambridge, USA; 1:750) diluted in PBS for $20 \mathrm{~min}$ at $25^{\circ} \mathrm{C}$. Then, the sections were incubated with the biotinylated goat anti-rabbit secondary antibody for $20 \mathrm{~min}$. After incubation with streptavidin peroxidase, the desired stain intensity was obtained with $\mathrm{DAB}$ by visualizing under the microscope. The slices were lightly counterstained with hematoxylin (Beyotime Institute of Biotechnology, China), dehydrated with ethanol, and mounted. Fifteen random crypts in each slice were analyzed. The total number of crypt cells and the number of Ki-67 positive cells (brown cells) in each crypt were counted to calculate the percentage of proliferative cells.

\section{Tissue homogenate}

Approximately $2.0 \mathrm{~g}$ mucosal samples were minced and placed in ice-cold $154 \mathrm{mmol} / \mathrm{L}$ sterile sodium chloride solution (1:9, wt/vol), which were subsequently homogenized with an Ultra-Turrax homogenizer (Tekmar, Cincinnati, USA) at 13,500 r/m for $1 \mathrm{~min}$. Then, the homogenate was centrifuged at $4,000 \times g$ for $20 \mathrm{~min}$ at $4{ }^{\circ} \mathrm{C}$, and the 
supernatant was analyzed rapidly. The protein concentrations in the homogenate were quantified using a bicinchoninic acid assay kit obtained from the Beyotime Institute of Biotechnology (China).

\section{Mucosal immune status assay}

The levels of cytokines (tumor necrosis factor alpha (TNF- $\alpha$ ), interferon gamma (IFN- $\gamma$ ), interleukin (IL)-1 $\beta$, IL-4, IL-6, and IL-10) in the intestinal mucosa were determined using the ProcartaPlex ${ }^{\mathrm{Tm}}$ multiplex immunoassay (Luminex, Austin, USA) kit according to the manufacturer's instruction obtained from Affymetrix eBioscience (Santa Clara, USA). The concentrations of monocyte chemotactic protein 1 (MCP-1), mucin 2 (MUC2), and trefoil factor 3 (TFF3) were measured by ELISA using porcine-specific kits (CUSABIO Biotech, Wuhan, China). The detection ranges were 31.25 to 2,000 $\mathrm{pg} / \mathrm{mL}$ for MCP-1, 7.8 to $500 \mathrm{ng} / \mathrm{mL}$ for MUC2, and 1.25 to $80 \mathrm{ng} / \mathrm{mL}$ for TFF3. The minimum detectable doses were $<7.81 \mathrm{pg} / \mathrm{mL},<1.95 \mathrm{ng} / \mathrm{mL}$, and $<0.3125 \mathrm{ng} / \mathrm{mL}$ for MCP-1, MUC2, and TFF3, respectively. In addition, the inter- and intra-assay coefficients of variance were $<5 \%$ and $<10 \%$ for MCP $-1,<8 \%$ and $<10 \%$ for MUC2, and $<8 \%$ and $<10 \%$ for TFF3. Furthermore, myeloperoxidase (MPO) activity was measured using a colorimetric kit (Nanjing Jiancheng Institute of Bioengineering, Nanjing, China). All procedures were performed strictly following the manufacturers' guidelines and the results were normalized against total protein concentration in each sample for inter-sample comparison.

\section{Quantification of intestinal microbiota}

Bacterial DNA was extracted from the intestinal digesta samples using a TIANamp Stool DNA Kit (Tiangen, Beijing, China) according to the manufacturer's instructions. The concentration and quality of DNA were analyzed using ultraviolet absorbance (NanoDrop Technologies, Wilmington, USA). The integrity of DNA was checked by electrophoresis on $1.5 \%$ agarose gels. The primers for the genus Lactobacillus, Escherichia coli, Bacillus, Bifidobacterium, and total bacteria are shown in Table 2 as reported previously [33-37]. After PCR amplification with Taq DNA polymerase kit (TaKaRa Biotechnology, Dalian, China) and electrophoresis on a 1.5\% agarose gel, the PCR products were purified by a TIANgel Maxi Purification Kit (Tiangen, China) and cloned in Escherichia coli DH5 $\alpha$ (Tiangen, China) using the pMD18-T vector system (TaKaRa Biotechnology, China). The extracted plasmids containing targeted fragments to be sequenced commercially, obtaining the positive plasmids (Invitrogen, Shanghai, China).

The real-time absolute quantitative PCR reaction was applied to quantify the selected bacteria according to the method previously described [38]. Standard curves were generated with 10 -fold serial dilutions of the respective positive plasmids. The concentration of the positive plasmids was plotted against the threshold cycle $(\mathrm{Ct})$ value. The reaction was performed by SYBR Green fluorescence using the ABI StepOnePlus ${ }^{\mathrm{Tm}}$ Real-Time PCR System (Applied Biosystems, Foster City, USA). The mixture $(20 \mu \mathrm{L})$ of each reaction contained $2 \mu \mathrm{L}$ DNA template, $0.8 \mu \mathrm{L}$ of the primer pair, $10 \mu \mathrm{L}$ of a freshly premixed SYBR $^{\circ}$ Premix Ex Taq (TaKaRa Biotechnology, China), $0.4 \mu \mathrm{L}$ ROX reference dye (TaKaRa Biotechnology, China), and $6.8 \mu \mathrm{L}$ double-distilled $\mathrm{H}_{2} \mathrm{O}$. A control without template was included in all batches. The reaction protocol was composed of one cycle of denaturation at $95{ }^{\circ} \mathrm{C}$ for $30 \mathrm{~s}$, forty cycles of denaturation at $95{ }^{\circ} \mathrm{C}$ for $5 \mathrm{~s}$, followed by an annealing step according to the annealing temperature in Table 2 for $30 \mathrm{~s}$, followed by a product melting curve to determine the specificity of amplification. Each sample was run in triplicate. The functions describing the relationship between $\mathrm{Ct}$ and $X$ ( $\log _{10} 16 \mathrm{~S}$ rRNA gene copies/g contents) for the different assays were: $\mathrm{Ct}=-0.257 X+13.22 ; R^{2}=$ 0.9993 for total bacteria; $\mathrm{Ct}=-0.301 X+13.37 ; R^{2}=0.9992$ for Lactobacillus; $\mathrm{Ct}=-0.340 X+14.41 ; R^{2}=0.9996$ for Escherichia coli; $\mathrm{Ct}=-0.291 X+12.8 ; R^{2}=0.9992$ for

Table 2 Group-specific 16S-targeted primers and optimized conditions for real-time PCR

\begin{tabular}{|c|c|c|c|c|}
\hline Name & Sequence, $5^{\prime} \rightarrow 3^{\prime a}$ & Annealing temperature, ${ }^{\circ} \mathrm{C}$ & Product size, bp & Reference \\
\hline \multirow[t]{2}{*}{ Total bacteria } & ACTCCTACGGGAGGCAGCAG & 60 & 200 & [33] \\
\hline & ATTACCGCGGCTGCTGG & & & \\
\hline \multirow[t]{2}{*}{ Lactobacillus } & AGCAGTAGGGAATCTTCCA & 55 & 341 & [34] \\
\hline & CACCGCTACACATGGAG & & & \\
\hline \multirow[t]{2}{*}{ Escherichia coli } & CATGCCGCGTGTATGAAGAA & 60 & 96 & [35] \\
\hline & CGGGTAACGTCAATGAGCAAA & & & \\
\hline \multirow[t]{2}{*}{ Bacillus } & GCAACGAGCGCAACCCTTGA & 60 & 92 & [36] \\
\hline & TCATCCCCACCTTCCTCCGGT & & & \\
\hline \multirow[t]{2}{*}{ Bifidobacterium } & CTCCTGGAAACGGGTGG & 55 & 550 & [37] \\
\hline & GGTGTTCTTCCCGATATCTACA & & & \\
\hline
\end{tabular}


Bacillus; $\quad \mathrm{Ct}=-0.266 \quad X+12.32 ; \quad R^{2}=0.9990 \quad$ for Bifidobacterium.

\section{Total RNA isolation and quantitative real-time PCR analysis}

Total RNA was extracted from snap-frozen mucosal samples using the TRIzol Reagent (Invitrogen, Gaithersburg, USA). The concentration, quality, and integrity of RNA samples were performed as previously described [39]. After that, $1 \mu \mathrm{g}$ of total RNA was reverse-transcribed into complementary DNA (cDNA) using a PrimeScripte RT Reagent Kit following the instruction provided by TaKaRa Biotechnology (China). Real-time PCR was performed using the ABI StepOnePlus ${ }^{\mathrm{Ts}}$ Real-Time PCR System (Applied Biosystems, USA) with the One Step SYBR ${ }^{\curvearrowleft}$ PrimeScript $^{\text {Tm }}$ RT-PCR Kit (TaKaRa Biotechnology, China) following the manufacturers' instructions. Primer sequences of the target and reference genes (B-cell lymphoma/leukaemia $2(B C L-2)$, myeloid cell leukemia 1 $(M C L-1)$, B-cell lymphoma/leukaemia 2-associated $\mathrm{X}$ protein $(B A X)$, phospholipid scramblase 3 (PLSCR3), glyceraldehyde phosphate dehydrogenase (GAPDH), and $\beta$-actin) are presented in Table 3 . Verification of the specificity of each primer pair was performed using NCBI Blast (http://www.ncbi.nlm.nih.gov). The thermal cycling parameters were as follows: one cycle of denaturation at $95{ }^{\circ} \mathrm{C}$ for $30 \mathrm{~s}$, forty cycles of denaturation at $95^{\circ} \mathrm{C}$ for $5 \mathrm{~s}$, followed by an annealing step at $60{ }^{\circ} \mathrm{C}$ for $30 \mathrm{~s}$. To determine the specificity of amplification, a product melting curve analysis was carried out. In addition, the standard curve of each gene was run in triplicate for obtaining reliable amplification efficiency. The correlation coefficients of all standard curves were $>0.99$ and the efficiency values

Table 3 Primer sequences used for real-time PCR assay

\begin{tabular}{|c|c|c|c|}
\hline $\mathrm{Name}^{\mathrm{a}}$ & GenBank $^{\mathrm{b}}$ & Sequence, $5^{\prime} \rightarrow 3^{\prime c}$ & Length, bp \\
\hline \multirow[t]{2}{*}{$B C L-2$} & XM_003121700.4 & ATCAAGTGTTCCGCGTGACT & 138 \\
\hline & & GGGTACCAACAGCACCTCTC & \\
\hline \multirow[t]{2}{*}{$M C L-1$} & NM_214361.1 & GCCTTTGTGGCCAAACACTT & 129 \\
\hline & & CCCATCCCAGCCTCTITGTT & \\
\hline \multirow[t]{2}{*}{$B A X$} & XM_005664710.2 & GAAACTCCTGGATCCGACGC & 130 \\
\hline & & TCTGGGGTTCTCCAGCTTCT & \\
\hline \multirow[t]{2}{*}{ PLSCR3 } & XM_005669207.2 & TGTTCTAGGGGCTTCAGACG & 158 \\
\hline & & GTGTCCCGGAGGCTTAGTTC & \\
\hline \multirow[t]{2}{*}{ GAPDH } & NM_001206359.1 & CCAAGGAGTAAGAGCCCCTG & 125 \\
\hline & & AAGTCAGGAGATGCTCGGTG & \\
\hline \multirow[t]{2}{*}{$\beta$-actin } & XM_003124280.4 & CTCCAGAGCGCAAGTACTCC & 153 \\
\hline & & AATGCAACTAACAGTCCGCC & \\
\hline
\end{tabular}

${ }^{\mathrm{a} B A X}$ B-cell CLL/lymphoma 2-associated $\mathrm{X}$ protein, $\beta$-actin beta actin, $B C L-2$ B-cell CLL/lymphoma 2, GAPDH glyceraldehyde phosphate dehydrogenase, MCL-1 myeloid cell leukemia 1, PLSCR3 phospholipid scramblase 3

${ }^{\mathrm{b}} \mathrm{GenB}$ Bank Accession Number

'Shown as forward primer followed by reverse primer were between 95 and 103\%. The mRNA expression levels were calculated using the $2^{-\Delta \Delta \mathrm{Ct}}$ method [40]. All the data were normalized to those of the reference gene GAPDH.

\section{Statistical analysis}

Data were tested for normality (Shapiro-Wilk test) and homogeneity of variances (Levene's test) prior to statistical analysis. Data that were heterogeneous or not normally distributed were analyzed using non-parametric Kruskal-Wallis test, and pairwise differences in rank sums were evaluated using selected comparisons tests. All normal data were tested for statistical significance using one-way ANOVA and Tukey's post hoc test for pairwise comparisons. Data were analyzed by using SPSS statistical software (ver. 22.0 for Windows, SPSS Inc., Chicago, USA). The $P$ values less than 0.05 were considered as statistically significant. Results are presented as means with standard errors of the mean (SEM).

\section{Results \\ Growth performance}

During the first $4 \mathrm{wk}$ after weaning, ADG and ADFI were significantly lower in the IUGR-CON piglets than in the NBW-CON piglets $(P<0.05$; Table 4$)$. Supplementation with BA effectively improved the growth performance of the IUGR-BA group, as indicated by their increases in ADG and FE $(P<0.05)$. However, the BA-supplemented diet did not alter the ADFI of the piglets $(P>0.05)$.

\section{Intestinal morphology, cell proliferation, and apoptosis}

Morphological results indicated that IUGR reduced the $\mathrm{VH}$ and the ratio of $\mathrm{VH}$ to $\mathrm{CD}$ in the jejunum and in the ileum $(P<0.05)$, whereas the $C D$ was not altered $(P>0.05$; Table 5). In contrast, the jejunal $\mathrm{VH}: \mathrm{CD}$ ratio and ileal $\mathrm{VH}$ were greater in the IUGR-BA piglets than in the non-treated IUGR piglets $(P<0.05)$.

Compared with the NBW-CON piglets, IUGR induced a significantly increased proliferation of ileal crypt cells (Fig. 2), but there was no effect in the jejunum $(P<0.05$; Table 6). The numbers of apoptotic cells (Fig. 3) were greater in the jejuna and the ilea of IUGR-CON group than of the NBW-CON group $(P<0.05)$. Conversely, apoptosis rates were significantly decreased in the small intestines of the IUGR piglets fed the BA-supplemented diet compared with those fed the control diet $(P<0.05)$. In addition, the IUGR-BA group showed a lower proportion than the IUGR-CON group of crypt proliferative cells in their ilea $(P<0.05)$.

The expression levels of genes related to apoptosis are summarized in Table 7. IUGR was found to decrease $B C L-2$ mRNA abundance in the jejuna and the ilea of the IUGR-CON piglets compared to the NBW-CON piglets $(P<0.05)$. However, the mRNA levels of intestinal 
Table 4 Effects of Bacillus amyloliquefaciens on growth performance of weanling piglets with intra-uterine growth retardation

\begin{tabular}{|c|c|c|c|c|c|c|}
\hline \multirow[t]{2}{*}{ Items ${ }^{a, b}$} & \multirow[t]{2}{*}{ NBW-CON (NC group) } & \multirow[t]{2}{*}{ IUGR-CON (IC group) } & \multirow[t]{2}{*}{ IUGR-BA (IB group) } & \multirow[t]{2}{*}{ SEM } & \multicolumn{2}{|l|}{ Contrast } \\
\hline & & & & & NC vs. IC & IC vs. IB \\
\hline $\mathrm{ADG}^{\mathrm{b}}, \mathrm{g} / \mathrm{d}$ & 362.74 & 255.89 & 301.85 & 12.31 & $<0.001$ & 0.033 \\
\hline$A D F I^{b}, g / d$ & 577.23 & 429.02 & 470.02 & 18.44 & $<0.001$ & 0.320 \\
\hline $\mathrm{FE}^{\mathrm{b}}, \mathrm{g} / \mathrm{g}$ & 0.63 & 0.60 & 0.64 & 0.01 & 0.115 & 0.026 \\
\hline
\end{tabular}

${ }^{a} A D F I$ average daily feed intake, $A D G$ average daily weight gain, $F E$ feed efficiency, IUGR-BA piglets with intrauterine growth retardation fed the Bacillus amyloliquefaciens-supplemented diet, IUGR-CON piglets with intrauterine growth retardation fed the control diet, NBW-CON piglets with normal birth weight fed the control diet

${ }^{b}$ One-way ANOVA test. A value of $P<0.05$ was considered as statistically significant

$M C L-1, B A X$, and PLSCR3 were not affected by IUGR $(P>0.05)$. In addition, BA had no effect on the expression levels of BCL-2, MCL-1, BAX, or PLSCR3 ( $P>0.05)$.

\section{Intestinal immune status}

MCP-1 concentration and MPO activity were higher in the jejuna and the ilea of the IUGR-CON piglets than of the NBW-CON piglets $(P<0.05$; Table 8$)$. A similar effect induced by IUGR was observed for TNF- $\alpha$ and IL-1 $\beta$ levels in the jejuna of the control piglets $(P<0.05)$. IUGR significantly decreased the ileal IL-10 content of the control piglets compared with the NBW-CON piglets $(P<0.05)$. However, feeding the IUGR piglets with the BA-supplemented diet effectively increased IL-10 content but decreased TNF- $\alpha$ level in both the jejunum and ileum compared with the control diet $(P<0.05)$. In the ileum, BA supplementation decreased the activity of MPO in the IUGR-BA group compared with the IUGR-CON group $(P<0.05)$. Neither IUGR nor BA supplementation affected the IFN- $\gamma$, IL-4, or IL-6 levels in the small intestine $(P>0.05)$.

As shown in Table 9, IUGR decreased TFF3 content but had no effect on goblet cell numbers (Fig. 4) or MUC2 content in the jejuna of the IUGR-CON group, when compared with the NBW-CON group $(P<0.05)$. In the ileum, goblet cell density and MUC2 and TFF3 concentrations were greatly reduced in the IUGR-CON piglets compared to the NBW-CON group $(P<0.05)$.
However, the adverse effects that IUGR exerted in ileal goblet cell density and MUC2 and TFF3 productions were attenuated by BA supplementation $(P<0.05)$. In addition, feeding the IUGR piglets with the BA diet did not alter these parameters in the jejunum $(P>0.05)$.

\section{Microbiota populations}

The IUGR-CON piglets showed increased Escherichia coli but decreased Bifidobacterium abundance in the ileal digesta compared with the NBW-CON piglets $(P<0.05$; Table 10). Conversely, the numbers of Escherichia coli were significantly lower in the jejunal contents of the IUGR-BA piglets than those of the IUGR-CON piglets $(P<0.05)$. Supplementation of BA increased the populations of Lactobacillus and Bifidobacterium in the ileal digesta of the IUGR-BA group in comparison with the IUGR-CON group $(P<0.05)$. No differences were found among the groups in respect of abundance of total bacteria or Bacillus $(P>0.05)$.

\section{Discussion}

It has been reported that IUGR affects the development of the gastrointestinal tract and impairs the morphology of the small-intestinal mucosa in humans and in several animal models. The key role of the intestine in processing dietary molecules into available nutrients for the organism makes this a matter of great importance [41, 42]. The present study corroborates previous findings and

Table 5 Effects of Bacillus amyloliquefaciens on intestinal morphology of weanling piglets with intra-uterine growth retardation

\begin{tabular}{|c|c|c|c|c|c|c|c|}
\hline \multirow[t]{2}{*}{ Items $^{a}$} & & \multirow[t]{2}{*}{ NBW-CON (NC group) } & \multirow[t]{2}{*}{ IUGR-CON (IC group) } & \multirow[t]{2}{*}{ IUGR-BA (IB group) } & \multirow[t]{2}{*}{ SEM } & \multicolumn{2}{|l|}{ Contrast } \\
\hline & & & & & & NC vs. IC & IC vs. IB \\
\hline \multirow[t]{3}{*}{ Jejunum } & $V H^{c}, \mu m$ & 498.79 & 389.69 & 443.27 & 14.48 & 0.004 & 0.433 \\
\hline & $C D^{b}, \mu \mathrm{m}$ & 198.40 & 210.17 & 197.76 & 5.81 & 0.709 & 0.683 \\
\hline & $\mathrm{VH}: \mathrm{CD}$ ratio ${ }^{b}, \mu \mathrm{m} / \mu \mathrm{m}$ & 2.54 & 1.88 & 2.24 & 0.08 & $<0.001$ & 0.040 \\
\hline \multirow[t]{3}{*}{ Ileum } & $V H^{b}, \mu m$ & 414.52 & 352.21 & 400.62 & 9.12 & 0.005 & 0.029 \\
\hline & $C D^{c}, \mu \mathrm{m}$ & 177.82 & 185.08 & 175.72 & 3.87 & NS & NS \\
\hline & $\mathrm{VH}: \mathrm{CD}$ ratio ${ }^{\mathrm{b}}, \mu \mathrm{m} / \mu \mathrm{m}$ & 2.34 & 1.92 & 2.30 & 0.07 & 0.035 & 0.063 \\
\hline
\end{tabular}

${ }^{a} C D$ crypt depth, IUGR-BA piglets with intrauterine growth retardation fed the Bacillus amyloliquefaciens-supplemented diet, IUGR-CON piglets with intrauterine growth retardation fed the control diet, NBW-CON piglets with normal birth weight fed the control diet, NS nonsignificant values after Kruskal-Wallis comparison test, $V H$ villus height, $V H: C D$ ratio the ratio of villus height to crypt depth

b One-way ANOVA test. A value of $P<0.05$ was considered as statistically significant

${ }^{c}$ Non-parametric Kruskal-Wallis test. A value of $P<0.05$ was considered as statistically significant 


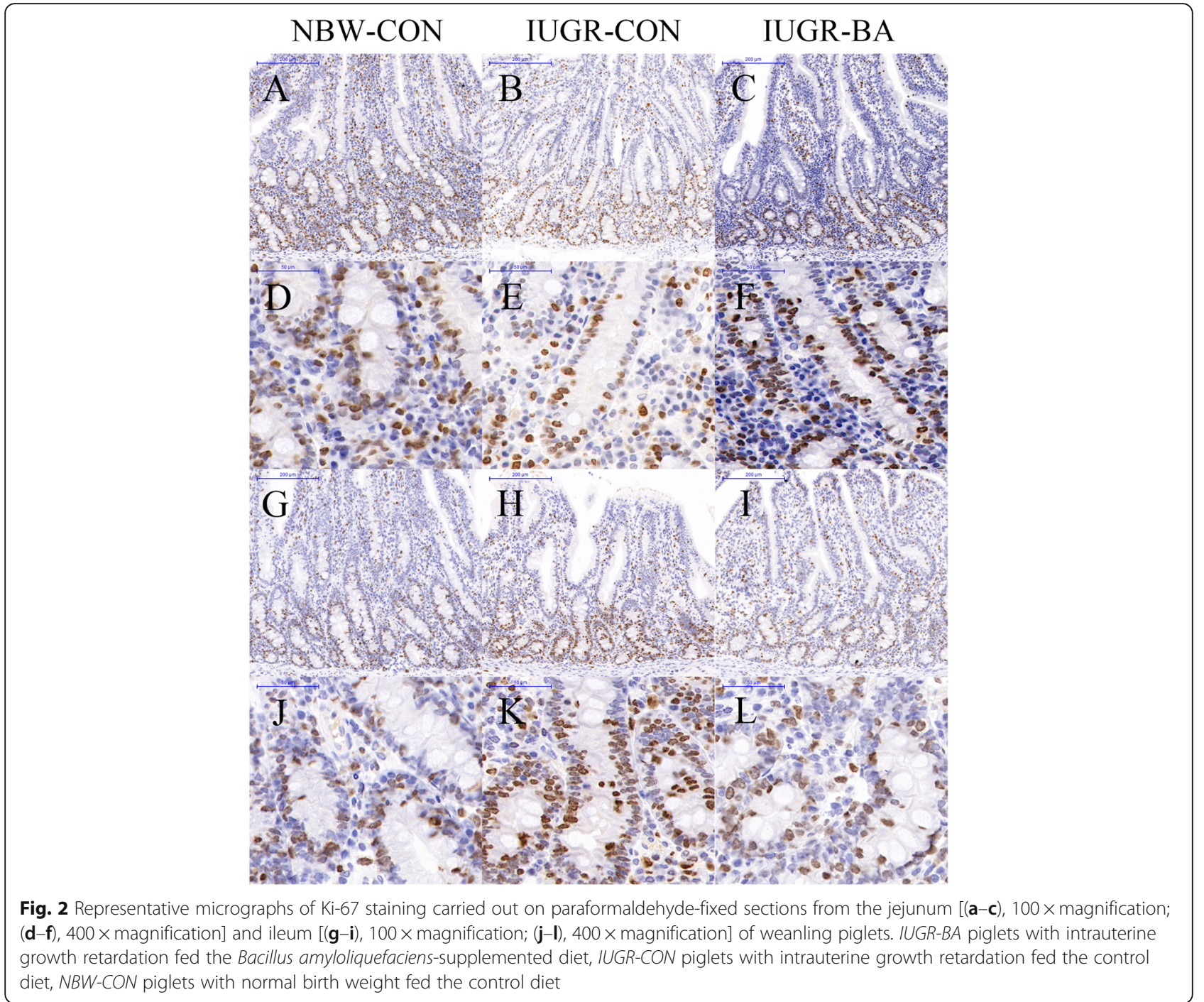

Table 6 Effects of Bacillus amyloliquefaciens on intestinal cell proliferation and apoptosis of weanling piglets with intra-uterine growth retardation

\begin{tabular}{|c|c|c|c|c|c|c|c|}
\hline \multirow[t]{2}{*}{ Items $^{a}$} & & \multirow[t]{2}{*}{ NBW-CON (NC group) } & \multirow[t]{2}{*}{ IUGR-CON (IC group) } & \multirow[t]{2}{*}{ IUGR-BA (IB group) } & \multirow[t]{2}{*}{ SEM } & \multicolumn{2}{|l|}{ Contrast } \\
\hline & & & & & & NC vs. IC & IC vs. IB \\
\hline \multirow[t]{2}{*}{ Jejunum } & $\begin{array}{l}\text { Ki- } 67 \text { positive cell percentage } \\
\text { per crypt }{ }^{b}, \%\end{array}$ & 42.28 & 46.25 & 41.10 & 1.21 & 0.366 & 0.198 \\
\hline & $\begin{array}{l}\text { TUNEL positive cell percentage } \\
\text { per } 100 \text { cells of villus }{ }^{b}, \%\end{array}$ & 7.82 & 12.46 & 9.88 & 0.58 & 0.001 & 0.038 \\
\hline \multirow[t]{2}{*}{ Ileum } & $\begin{array}{l}\text { Ki- } 67 \text { positive cell percentage } \\
\text { per } \text { crypt }^{b}, \%\end{array}$ & 39.79 & 50.55 & 39.02 & 1.93 & 0.030 & 0.020 \\
\hline & $\begin{array}{l}\text { TUNEL positive cell percentage } \\
\text { per } 100 \text { cells of villus }{ }^{\mathrm{b}}, \%\end{array}$ & 8.06 & 13.93 & 6.93 & 0.91 & 0.002 & $<0.001$ \\
\hline
\end{tabular}

aIUGR-BA piglets with intrauterine growth retardation fed the Bacillus amyloliquefaciens-supplemented diet, IUGR-CON piglets with intrauterine growth retardation fed the control diet, NBW-CON piglets with normal birth weight fed the control diet

b One-way ANOVA test. A value of $P<0.05$ was considered as statistically significant 


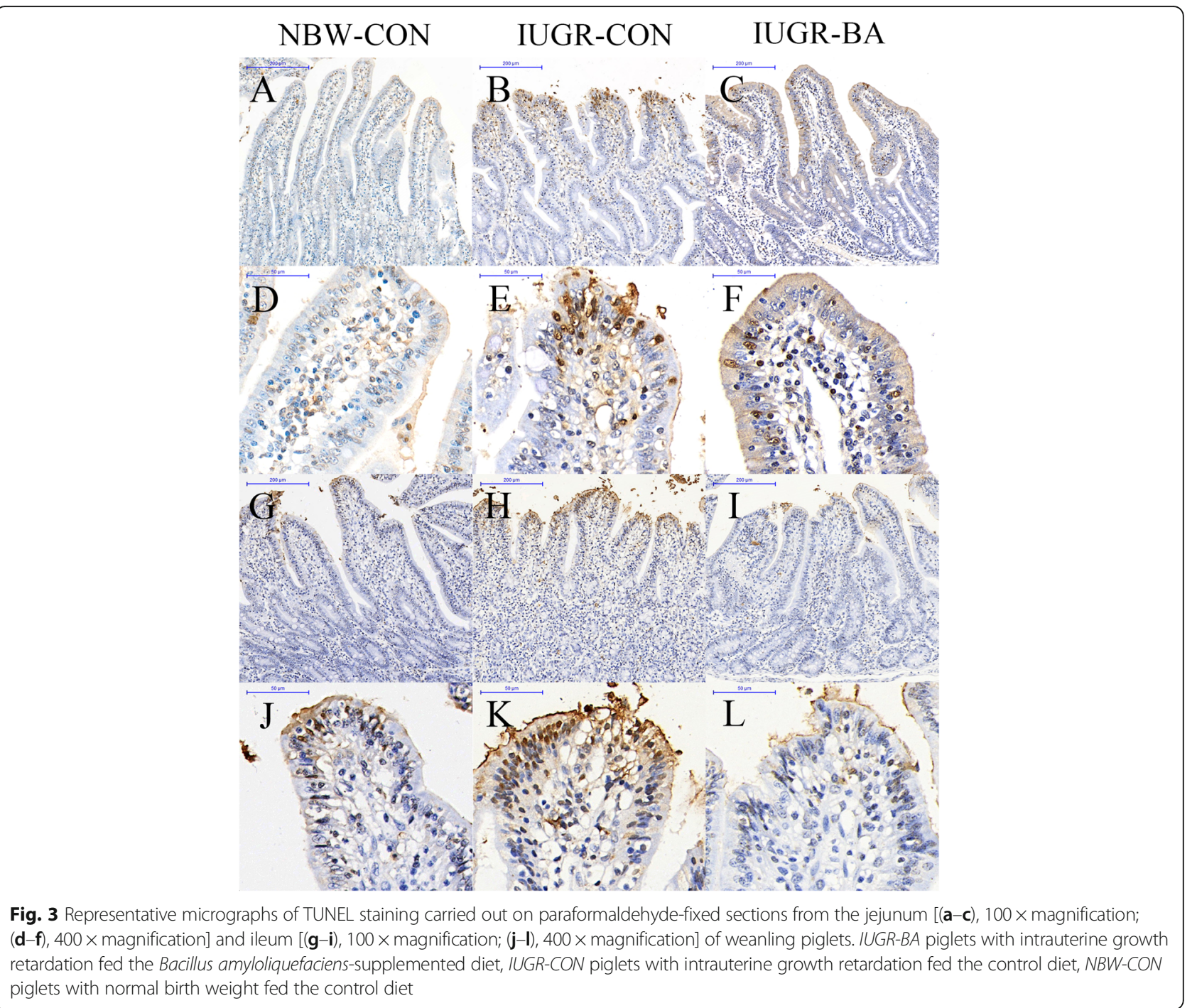

Table 7 Effects of Bacillus amyloliquefaciens on apoptosis-associated gene expression of weanling piglets with intra-uterine growth retardation

\begin{tabular}{|c|c|c|c|c|c|c|c|}
\hline \multirow[t]{2}{*}{ Items $^{a}$} & & \multirow{2}{*}{$\begin{array}{l}\text { NBW-CON } \\
\text { (NC group) }\end{array}$} & \multirow{2}{*}{$\begin{array}{l}\text { IUGR-CON } \\
\text { (IC group) }\end{array}$} & \multirow{2}{*}{$\begin{array}{l}\text { IUGR-BA } \\
\text { (IB group) }\end{array}$} & \multirow[t]{2}{*}{ SEM } & \multicolumn{2}{|l|}{ Contrast } \\
\hline & & & & & & NC vs. IC & IC vs. IB \\
\hline \multirow[t]{4}{*}{ Jejunum } & $B C L-2^{C}$ & 1.00 & 0.53 & 0.80 & 0.08 & 0.033 & 0.092 \\
\hline & $M C L-1^{b}$ & 1.00 & 0.66 & 0.85 & 0.07 & 0.081 & 0.402 \\
\hline & $B A X^{\infty}$ & 1.00 & 1.61 & 1.27 & 0.13 & 0.123 & 0.491 \\
\hline & PLSCR3 ${ }^{\mathrm{b}}$ & 1.00 & 1.08 & 1.03 & 0.14 & 0.969 & 0.988 \\
\hline \multirow[t]{4}{*}{ Ileum } & $B C L-2^{b}$ & 1.00 & 0.53 & 0.89 & 0.08 & 0.017 & 0.067 \\
\hline & $M C L-1^{\mathrm{b}}$ & 1.00 & 0.81 & 1.01 & 0.08 & 0.626 & 0.606 \\
\hline & $B A X^{C}$ & 1.00 & 1.64 & 1.08 & 0.11 & NS & NS \\
\hline & PLSCR3 ${ }^{\mathrm{b}}$ & 1.00 & 0.94 & 0.86 & 0.07 & 0.952 & 0.890 \\
\hline
\end{tabular}

${ }^{a} B A X$ B-cell lymphoma/leukaemia 2-associated X protein, $B C L-2$ B-cell CLL/lymphoma 2, IUGR-BA piglets with intrauterine growth retardation fed the Bacillus amyloliquefaciens-supplemented diet, IUGR-CON piglets with intrauterine growth retardation fed the control diet, NBW-CON piglets with normal birth weight fed the control diet, NS nonsignificant values after Kruskal-Wallis comparison test, MCL-1 myeloid cell leukemia 1, PLSCR3 phospholipid scramblase 3

bone-way ANOVA test. A value of $P<0.05$ was considered as statistically significant

${ }^{c}$ Non-parametric Kruskal-Wallis test. A value of $P<0.05$ was considered as statistically significant 
Table 8 Effects of Bacillus amyloliquefaciens on intestinal immune status of weanling piglets with intra-uterine growth retardation

\begin{tabular}{|c|c|c|c|c|c|c|c|}
\hline \multicolumn{2}{|l|}{ Items $^{a}$} & \multirow{2}{*}{$\begin{array}{l}\text { NBW-CON } \\
\text { (NC group) }\end{array}$} & \multirow{2}{*}{$\begin{array}{l}\text { IUGR-CON } \\
\text { (IC group) }\end{array}$} & \multirow{2}{*}{$\begin{array}{l}\text { IUGR-BA } \\
\text { (IB group) }\end{array}$} & \multirow[t]{2}{*}{ SEM } & \multicolumn{2}{|l|}{ Contrast } \\
\hline & & & & & & NC vs. IC & IC vs. IB \\
\hline \multirow[t]{8}{*}{ Jejunum } & TNF-a ${ }^{b}, p g / m g$ protein & 0.90 & 1.61 & 0.84 & 0.13 & 0.038 & 0.024 \\
\hline & IFN- $\gamma^{\mathrm{b}}, \mathrm{pg} / \mathrm{mg}$ protein & 1.52 & 2.13 & 1.44 & 0.13 & 0.093 & 0.054 \\
\hline & $\mathrm{IL}-1 \beta^{\mathrm{b}}, \mathrm{pg} / \mathrm{mg}$ protein & 4.37 & 8.56 & 5.49 & 0.64 & 0.011 & 0.062 \\
\hline & $\mathrm{IL}-4^{\mathrm{b}}, \mathrm{pg} / \mathrm{mg}$ protein & 1.26 & 1.27 & 1.54 & 0.08 & 0.998 & 0.406 \\
\hline & $\mathrm{IL}-6^{\mathrm{b}}, \mathrm{pg} / \mathrm{mg}$ protein & 1.71 & 3.10 & 2.34 & 0.29 & 0.120 & 0.495 \\
\hline & $\mathrm{IL}-10^{\mathrm{b}}, \mathrm{pg} / \mathrm{mg}$ protein & 19.09 & 14.40 & 22.22 & 1.30 & 0.227 & 0.029 \\
\hline & MCP-1 ${ }^{\mathrm{b}}, \mathrm{pg} / \mathrm{mg}$ protein & 5.30 & 7.30 & 5.88 & 0.34 & 0.031 & 0.140 \\
\hline & $\mathrm{MPO}^{c}, \mathrm{IU} / \mathrm{g}$ protein & 25.24 & 61.00 & 29.68 & 5.25 & 0.005 & 0.052 \\
\hline \multirow[t]{8}{*}{ Ileum } & TNF-a ${ }^{b}, p g / m g$ protein & 1.20 & 1.68 & 1.00 & 0.10 & 0.082 & 0.012 \\
\hline & IFN- $\gamma^{\mathrm{b}}, \mathrm{pg} / \mathrm{mg}$ protein & 1.93 & 2.24 & 1.57 & 0.15 & 0.632 & 0.148 \\
\hline & $\mathrm{IL}-1 \beta^{\mathrm{c}}, \mathrm{pg} / \mathrm{mg}$ protein & 6.66 & 13.78 & 7.06 & 1.17 & 0.092 & 0.080 \\
\hline & $\mathrm{IL}-4^{\mathrm{b}}, \mathrm{pg} / \mathrm{mg}$ protein & 0.79 & 0.80 & 1.06 & 0.06 & 0.999 & 0.211 \\
\hline & $\mathrm{IL}-6^{\mathrm{b}}, \mathrm{pg} / \mathrm{mg}$ protein & 1.80 & 1.84 & 2.03 & 0.15 & 0.994 & 0.872 \\
\hline & $\mathrm{IL}-10^{c}, \mathrm{pg} / \mathrm{mg}$ protein & 22.38 & 12.30 & 25.76 & 1.79 & 0.028 & 0.004 \\
\hline & MCP-1 $1^{\mathrm{b}}, \mathrm{pg} / \mathrm{mg}$ protein & 5.37 & 8.67 & 7.17 & 0.54 & 0.025 & 0.394 \\
\hline & $\mathrm{MPO}^{\mathrm{b}}, \mathrm{IU} / \mathrm{g}$ protein & 38.41 & 73.12 & 49.48 & 4.59 & 0.001 & 0.020 \\
\hline
\end{tabular}

aIFN- $\gamma$ interferon gamma, IL-1 $\beta$ interleukin 1 beta, IL-4 interleukin 4; IL-6 interleukin 6, IL-10 interleukin 10, IUGR-BA piglets with intrauterine growth retardation fed the Bacillus amyloliquefaciens-supplemented diet, IUGR-CON piglets with intrauterine growth retardation fed the control diet, $M C P$ - 1 monocyte chemotactic protein 1, MPO myeloperoxidase, NBW-CON piglets with normal birth weight fed the control diet, TNF- $a$ tumor necrosis factor alpha

${ }^{b}$ One-way ANOVA test. A value of $P<0.05$ was considered as statistically significant

${ }^{c}$ Non-parametric Kruskal-Wallis test. A value of $P<0.05$ was considered as statistically significant

suggests that the lower villus sizes were probably related to the disturbance in the balance of cell proliferation and apoptosis. Excessive apoptosis of villus cells can cause shortening of the villi [43], and the TUNEL staining showed higher rates of apoptotic cells in both the jejuna and the ilea of the IUGR piglets. Additionally, the intestinal expression pattern of apoptosis-related genes of the IUGRCON piglets differed from that of their heavier counterparts. Consistent with the increased proportion of cell apoptosis, a decreased abundance of $B C L-2$ mRNA was noted in the IUGR-CON piglets, which may reflect compromised anti-apoptotic function of BCL-2 in the small intestine. Similar results have been seen in rodent models of IUGR, where levels of $B C L-2$ mRNA were significantly down-regulated in the brain, kidneys, and ileum $[3,44,45]$. BCL-2 is an anti-apoptotic protein that attenuates the release of cytochrome $\mathrm{c}$ from mitochondria and counteracts the effects of BAX. Low levels of BCL-2 may be responsible

Table 9 Effects of Bacillus amyloliquefaciens on intestinal goblet cell density and mucin 2 and trefoil factor 3 contents of weanling piglets with intra-uterine growth retardation

\begin{tabular}{|c|c|c|c|c|c|c|c|}
\hline \multirow[t]{2}{*}{ Items $^{a}$} & & \multirow{2}{*}{$\begin{array}{l}\text { NBW-CON } \\
\text { (NC group) }\end{array}$} & \multirow{2}{*}{$\begin{array}{l}\text { IUGR-CON } \\
\text { (IC group) }\end{array}$} & \multirow{2}{*}{$\begin{array}{l}\text { IUGR-BA } \\
\text { (IB group) }\end{array}$} & \multirow[t]{2}{*}{ SEM } & \multicolumn{2}{|l|}{ Contrast } \\
\hline & & & & & & NC vs. IC & IC vs. IB \\
\hline \multirow[t]{3}{*}{ Jejunum } & $\begin{array}{l}\text { Goblet cell density }{ }^{b}, \mathrm{n} / 100 \mu \mathrm{m} \\
\text { of villus height }\end{array}$ & 2.89 & 2.69 & 2.72 & 0.07 & 0.540 & 0.982 \\
\hline & $\mathrm{MUC2}^{\mathrm{C}}, \mathrm{ng} / \mathrm{mg}$ protein & 12.52 & 8.04 & 8.92 & 0.95 & NS & NS \\
\hline & TFF $3^{\mathrm{b}}, \mathrm{ng} / \mathrm{mg}$ protein & 107.69 & 83.22 & 93.88 & 3.72 & 0.012 & 0.340 \\
\hline \multirow[t]{3}{*}{ lleum } & $\begin{array}{l}\text { Goblet cell density }{ }^{\mathrm{b}}, \mathrm{n} / 100 \mu \mathrm{m} \\
\text { of villus height }\end{array}$ & 4.02 & 3.16 & 3.84 & 0.13 & 0.009 & 0.039 \\
\hline & $M U C 2^{b}, \mathrm{ng} / \mathrm{mg}$ protein & 17.75 & 6.99 & 13.89 & 1.36 & $<0.001$ & 0.016 \\
\hline & TFF $3^{\mathrm{b}}, \mathrm{ng} / \mathrm{mg}$ protein & 168.07 & 103.83 & 151.02 & 9.17 & 0.004 & 0.032 \\
\hline
\end{tabular}

${ }^{a}$ IUGR-BA piglets with intrauterine growth retardation fed the Bacillus amyloliquefaciens-supplemented diet, IUGR-CON piglets with intrauterine growth retardation fed the control diet, MUC2 mucin 2, NBW-CON piglets with normal birth weight fed the control diet, NS nonsignificant values after Kruskal-Wallis comparison test, TFF3 trefoil factor 3

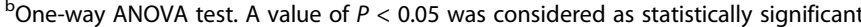

${ }^{c}$ Non-parametric Kruskal-Wallis test. A value of $P<0.05$ was considered as statistically significant 


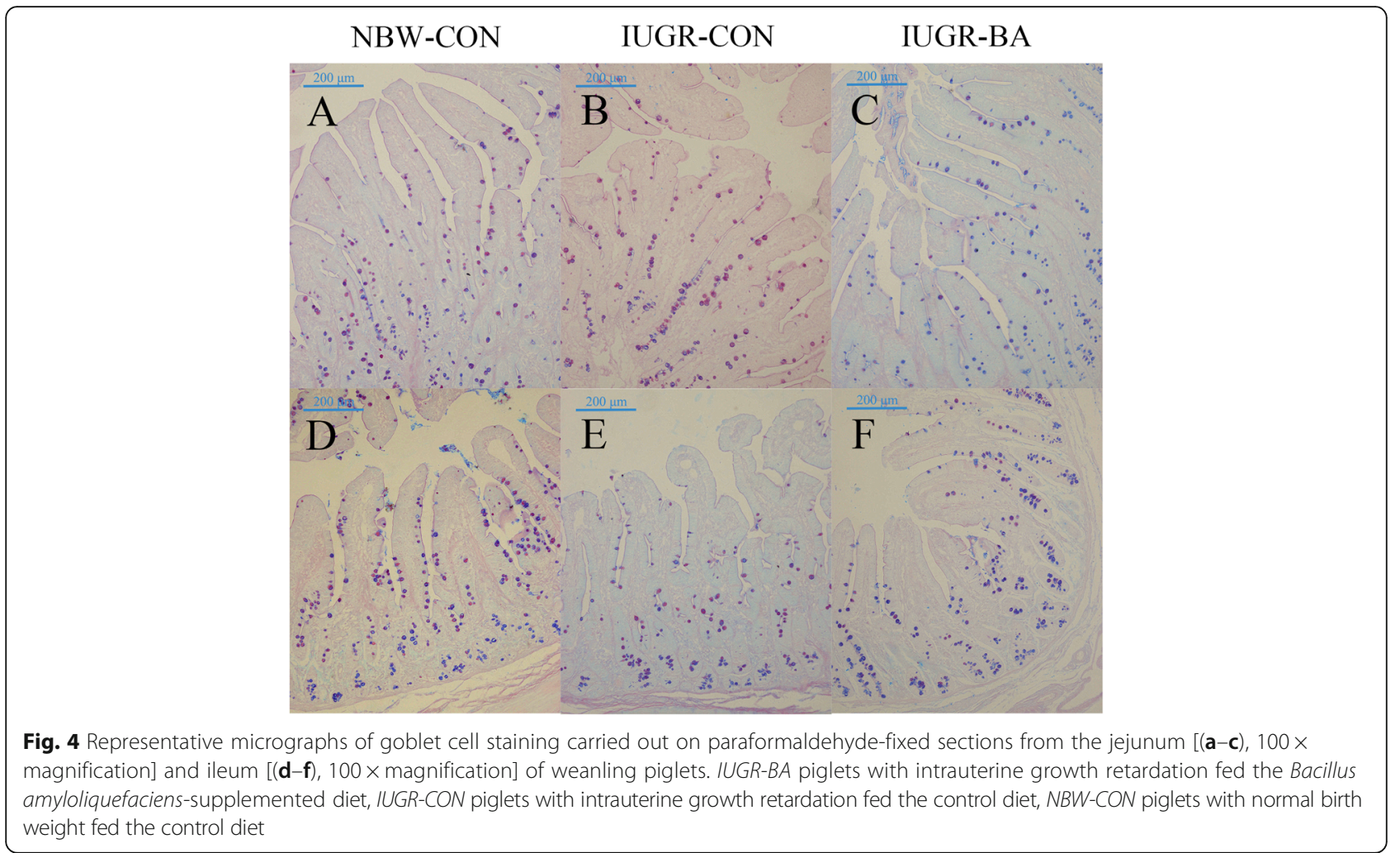

for the higher apoptotic index in the small intestines of the IUGR piglets. Moreover, it is noteworthy that IUGR induced a greater proportion of crypt proliferative cells in the ilea of the IUGR-CON piglets, which may imply a compensatory process in response to the excessive apoptosis in the villus.

Impairment of intestinal structure resulting from IUGR could induce a vicious cycle of bacterial invasion, immune activation, and uncontrolled inflammation.
Indeed, IUGR is known to predispose neonates to intestinal inflammatory diseases [46]. The mechanism by which this occurs involves an imbalance of pro- and anti-inflammatory cytokines. The present study observed higher levels of pro-inflammatory cytokines TNF- $\alpha$ and IL-1 $\beta$ in the IUGR-CON group, but a lower content of anti-inflammatory cytokine IL-10. Contrary to these results, Han et al. [47] found that IUGR decreased the mRNA abundance of IL-1 $\beta$ in the ilea of IUGR neonates.

Table 10 Effects of Bacillus amyloliquefaciens on intestinal microbiota abundance of weanling piglets with intra-uterine growth retardation

\begin{tabular}{|c|c|c|c|c|c|c|c|}
\hline \multirow[t]{2}{*}{ Items $^{a}$} & & \multirow{2}{*}{$\begin{array}{l}\text { NBW-CON } \\
\text { (NC group) }\end{array}$} & \multirow{2}{*}{$\begin{array}{l}\text { IUGR-CON } \\
\text { (IC group) }\end{array}$} & \multirow{2}{*}{$\begin{array}{l}\text { IUGR-BA } \\
\text { (IB group) }\end{array}$} & \multirow[t]{2}{*}{ SEM } & \multicolumn{2}{|l|}{ Contrast } \\
\hline & & & & & & NC vs. IC & IC vs. IB \\
\hline \multirow[t]{5}{*}{ Jejunum } & Total bacteria ${ }^{b}, \log _{10}$ copies/g & 9.52 & 9.65 & 9.50 & 0.11 & 0.888 & 0.857 \\
\hline & Lactobacillus $^{\mathrm{b}}, \log _{10}$ copies/g & 6.75 & 6.61 & 7.09 & 0.17 & 0.942 & 0.502 \\
\hline & Escherichia colic, $\log _{10}$ copies/g & 6.20 & 6.87 & 6.00 & 0.14 & 0.223 & 0.028 \\
\hline & Bacillus ${ }^{\mathrm{b}}, \log _{10}$ copies/g & 4.38 & 4.39 & 4.69 & 0.11 & 1.000 & 0.507 \\
\hline & Bifidobacterium ${ }^{\mathrm{b}}, \log _{10}$ copies/g & 2.90 & 2.82 & 3.12 & 0.09 & 0.931 & 0.398 \\
\hline \multirow[t]{5}{*}{ Ileum } & Total bacteriac, $\log _{10}$ copies/g & 10.12 & 10.26 & 10.20 & 0.09 & NS & NS \\
\hline & Lactobacillus ${ }^{b}, \log _{10}$ copies/g & 7.79 & 7.02 & 8.03 & 0.17 & 0.105 & 0.030 \\
\hline & Escherichia colic, $\log _{10}$ copies/g & 6.12 & 7.20 & 6.39 & 0.16 & 0.033 & 0.198 \\
\hline & Bacillus ${ }^{c}, \log _{10}$ copies/g & 4.85 & 4.63 & 5.37 & 0.15 & NS & NS \\
\hline & Bifidobacterium $^{\mathrm{b}}, \log _{10}$ copies/g & 3.65 & 3.00 & 3.76 & 0.11 & 0.019 & 0.007 \\
\hline
\end{tabular}

a IUGR-BA piglets with intrauterine growth retardation fed the Bacillus amyloliquefaciens-supplemented diet, IUGR-CON piglets with intrauterine growth retardation fed the control diet, NBW-CON piglets with normal birth weight fed the control diet, NS nonsignificant values after Kruskal-Wallis comparison test ${ }^{b}$ One-way ANOVA test. A value of $P<0.05$ was considered as statistically significant

${ }^{\mathrm{c}}$ Non-parametric Kruskal-Wallis test. A value of $P<0.05$ was considered as statistically significant 
This discrepancy between the studies is likely due to the stage of growth. Weaning is associated with a transient inflammation of the gut, in parallel with an increased plasma IL-1 $\beta$ concentration and with gene expression in the intestines of piglets $[48,49]$. However, the weaningassociated intestinal inflammation usually becomes more serious and long-lasting with light piglets at birth, most likely owing to a postnatal delay in the maturation of the immune defense system.

Goblet cells can synthesize and secrete bioactive molecules that are components of mucus, such as mucins and trefoil factors [50]. The mucus layer coating the intestinal epithelium forms a physical barrier that protects against endogenous and exogenous irritants and microbial attachment and invasion [51]. So far, a number of mucins have been identified; among them, MUC2 is the predominant secretory mucin in the small intestine [52]. In this study, levels of MUC2 and TFF3 were lower in the intestines of the IUGR-CON piglets, particularly in the ilea, where the number of goblet cells was dramatically reduced. Of the possible mechanisms by which IUGR inhibits intestinal goblet cell density, one is overproduction of proinflammatory cytokines in response to potential inflammatory stimuli, which can lead to depletion of goblet cells [53]. Another possible explanation is the longer physical adaptation for weaning stress in the IUGR piglets, which would delay the process of the intestine regaining normal goblet cell function. Normally, goblet cell numbers in the villi decrease during the weaning process and begin to increase again from 3 to 15 days post-weaning [54]. However, IUGR has been found to reduce the numbers of colonic goblet cells in rats post-weaning (and even in young adult rats), and it is known to be accompanied by a reduction of MUC2 at both the mRNA and protein levels [55]. In fact, emerging evidence indicates that a delay in the development of the mucus barrier-and, in particular, a lower capacity of goblet cells for producing mucus as a response to infection-may explain why IUGR neonates are more susceptible to intestinal diseases [56, 57].

Further, the IUGR-CON piglets in the present study exhibited an elevated activity of ileal MPO, an enzyme which participates in tissue injury in a large number of inflammatory conditions by producing cytotoxic oxidants [58]. This increase may be a sign of inflammatory status. Moreover, an increased level of chemokine MCP-1, a potent chemoattractant capable of promoting monocyte recruitment into an inflammatory site, was observed in the intestines of the IUGR piglets. This would enable recruited cells to produce more pro-inflammatory mediators, thereby potentiating inflammation. If an inflammation cannot be controlled promptly, it will have adverse consequences for the growth performance of animals, mainly by diverting available nutrients away from growth processes and toward immunerelated processes [59].
Probiotic bacteria can regulate lymphocyte cytokine production and inflammatory responses [60]. Hairul Islam et al. [61] reported that BA could alleviate increased concentrations of pro-inflammatory mediators, such as TNF- $\alpha$ and IL- $1 \beta$ in a mouse model of colitis induced by dextran sulfate. The results of the present study further corroborate the ability of BA to temper IUGR-induced excessive secretion of TNF- $\alpha$ in the small intestine, which may be due to the simultaneous increase in IL-10 content after administration of BA. IL-10 has a potent anti-inflammatory effect in decreasing the overproduction of pro-inflammatory cytokines under immunological stress [62]. Thus, supplementation with BA may have helped to alleviate intestinal inflammatory responses in the IUGR piglets (probably by improving the balance of pro- and anti-inflammatory cytokines), and this beneficial effect was also supported by the decrease in MPO activity after BA-supplemented feeding.

The underlying mechanisms through which BA regulates the inflammatory status may relate to the release of surfactin. Surfactin is a bacterium-derived molecule that can be produced by several Bacillus species including BA. Eun et al. [63] revealed that surfactin is able to reduce the release of inflammation-related mediators, first by blocking the phosphorylation of inhibitor of nuclear factor kappa-B kinase, and then by nuclear translocation of nuclear factor-kappa B (NF-kB). In addition to inhibiting NF- $\kappa B$ activation, surfactin was found to suppress the signaling of signal transducer and activator of transcription (STAT)-1, which could facilitate the production of many pro-inflammatory molecules [64]. Meanwhile, Park et al. [64] found that surfactin increased the phosphorylation of STAT-3, a component of the homeostatic mechanism inducing anti-inflammatory gene transcription, such as IL-10 [65]. This observation may provide a mechanistic explanation for the increased IL-10 secretion observed in the intestines of IUGR-BA piglets. Similarly, a recent study reported that surfactin produced from a BA culture increased the secretion of IL-10 in the splenocytes of non-obese diabetic mice [66]. Thus, BA may have therapeutic potential to treat intestinal inflammation caused by IUGR.

The above-mentioned findings are also supported by morphologic observation. The changes in small-intestinal morphology observed here for the IUGR-BA piglets, and in particular the increases in $\mathrm{VH}$ and $\mathrm{VH}: \mathrm{CD}$ ratio, may indicate an improvement of intestinal health status. These observations are consistent with the findings of Cai et al. [67] in their study of weanling piglets receiving a BAbased direct-fed-microbial. Moreover, a recent study demonstrated a higher $\mathrm{VH}$ and a lower CD in the ilea of IUGR suckling piglets given diets that included Bacillus subtilis [68]. Subsequent TUNEL analysis revealed that supplementation with BA attenuated the increased apoptotic 
index in both the jejunum and ileum induced by IUGR. This action of BA in limiting excessive inflammation may provide a mechanistic explanation for the improved intestinal structure and cellular homeostasis. Other studies have provided significant evidence that probiotics and probiotic-derived soluble factor prevent epithelial apoptosis and the disruption of barrier function induced by pro-inflammatory mediators $[27,64,68,69]$. Furthermore, the present findings indicate that supplementation with BA strongly promoted the secretions of MUC2 and TFF3 in the ilea of the IUGR-BA piglets, which may be related to the simultaneous increase in goblet cell numbers. Similar results have also been achieved by the addition of various probiotics, such as VSL\#3 (a probiotic mixture containing four species of Lactobacilli and three species of Bifidobacteria) [70], Lactobacillus rhamnosus GG [71], Bacillus subtilis [72, 73], and BA [61, 74]. It is of particular interest that TFF3 has been shown to play an essential role in the maintenance and repair of the intestinal mucosa [75]. These effects may therefore indicate that BA has the potential to repair the impaired intestinal structure of newly weaned piglets with IUGR.

The present study revealed that the IUGR-CON piglets had less Bifidobacterium and more Escherichia coli in their ileal digesta than their non-IUGR littermates. This is in line with the findings of a previous study that found a lower amount of Bifidobacterium in the cecocolonic content of IUGR rats at several time points from birth to sexual maturation [15]. One possible explanation for perturbations in the normal pattern of microbiota in the IUGR-CON piglets may be associated with decreases in goblet cell numbers and MUC2 and TFF3 contents, as mentioned above. Changes in goblet cell function and in the chemical composition of intestinal mucus have been detected in response to a broad range of luminal insults, including alterations of the normal microbiota [76]. However, the IUGR-induced decrease in the Bifidobacterium population was counteracted by the administration of BA. A higher population of Lactobacillus was also noted in the IUGR-BA group. In addition to stimulating goblet cell function, BA serves as an aerobic bacterial species that can consume oxygen rapidly and then provide a favorable environment for the colonization of Lactobacillus and Bifidobacterium. Furthermore, BA has the ability to stimulate the secretion of lactic acid and thereby induces a drop in intestinal $\mathrm{pH}$, which is beneficial to the growth of Lactobacillus [77, 78].

Additionally, the inhibition of BA against Escherichia coli was observed in the jejunal contents of the IUGR-BA piglets in the current study. We previously found that BA is highly effective against potential pathogenic bacteria such as Escherichia coli, Bacillus cereus, and Salmonella typhimurium $[79,80]$, which indicates the potential of BA to inhibit pathogens in the gut. In poultry, BA has also been found to inhibit the growth of the pathogenic bacteria Clostridium perfringens and Escherichia coli, and to improve the feed conversion rate in poultry $[28,81]$. BA can secrete bacteriocins including subtilin and barnase, which suppress the growth of pathogens directly, and antimicrobial peptides produced by BA have been verified as bactericidal agents [82, 83]. Furthermore, increased numbers of Lactobacillus and Bifidobacterium may help to inhibit the growth of Escherichia coli, possibly by a phenomenon known as competitive exclusion [84]. Taken together, these effects indicate that BA may be beneficial in stabilizing the intestinal ecosystem of IUGR piglets by replenishing suppressed health-promoting bacteria and inhibiting the growth of potential pathogenic microbiota.

\section{Conclusions}

The results obtained in the present study provide evidence that the inclusion of BA in diets for the IUGR piglets contributes in a number of ways to their improved growth performance during the first 4 wk post-weaning, including improvements in intestinal morphology, a decrease in inflammatory response, and better regulation of microbiota. The findings of this study may therefore help in the development of novel nutrition strategies for IUGR infants to prevent intestinal diseases in early life.

\section{Additional file}

Additional file 1: Availability of data and materials. (XLSX $32 \mathrm{~kb}$ )

\section{Abbreviations}

ADFI: Average daily feed intake; ADG: Average daily gain; BA: Bacillus amyloliquefaciens; BAX: B-cell lymphoma/leukaemia 2-associated X protein; BCL-2: B-cell lymphoma/leukaemia 2; BW: Birth weight; CD: Crypt depth; cDNA: complementary DNA; Ct: Threshold cycle; DAB: Di-amino-benzidine; FE: Feed efficiency; GAPDH: Glyceraldehyde phosphate dehydrogenase; IFN-ץ: Interferon gamma; IL: Interleukin; IUGR: Intra-uterine growth retardation; MCL-1: Myeloid cell leukemia 1; MCP-1: Monocyte chemotactic protein 1; MPO: Myeloperoxidase; MUC2: Mucin 2; NBW: Normal body weight; NF-kB: Nuclear factor-kappa B; NS: Not significant; PLSCR3: Phospholipid scramblase 3; STAT: Signal transducer and activator of transcription; TFF3: Trefoil factor 3; TNF-a: Tumor necrosis factor alpha; TUNEL: Terminal deoxynucleotidyl transferase-mediated deoxyuridine triphosphate nick end labeling; VH: Villus height

\section{Acknowledgements \\ The research was supported by the National Science-Technology Support Plan Projects of China (No. 2013BAD10B02-03) and the Phase II Project Funded by the Priority Academic Program Development of Jiangsu Higher Education Institutions. We acknowledge the help in VH and CD measurements, as well as the counting of Ki-67 and TUNEL positive cells and goblet cells from Xundong Wang at Nanjing Agricultural University, Nanjing, China.}

\section{Funding}

Funding for this study was provided by the National Science-Technology Support Plan Projects of China (No. 2013BAD10B02-03) and the Phase II Project Funded by the Priority Academic Program Development of Jiangsu Higher Education Institutions. The funding sources had no role in the study design, collection, analysis or interpretation of the data, writing of the manuscript, or the decision to submit the paper for publication. 


\section{Availability of data and materials}

All data generated or analyzed during this study are included in this published article and its Additional file 1.

\section{Authors' contributions}

The contributions of the authors are as follows: YL and TW participated in study design. YL, HZ, WS, ZY, YC, and LZ conducted animal experiment, biochemical parameter analysis, and data interpretation. ZL provided materials and reagents. $Y L, H Z$, and TW discussed the results. $Y L$ and $H Z$ wrote the paper. TW was in charge of the whole trial. All authors read and approved the final manuscript.

\section{Ethics approval}

All experiments were conducted in accordance with the guidelines established by the Institutional Animal Care and Use Committee of Nanjing Agricultural University (NJAU-CAST-2016-036).

\section{Consent for publication}

Not applicable.

\section{Competing interests}

The authors declare that they have no competing interests.

\section{Author details}

${ }^{1}$ College of Animal Science and Technology, Nanjing Agricultural University, Nanjing, Jiangsu 210095, China. ${ }^{2}$ College of Food Science and Technology, Nanjing Agricultural University, Nanjing, Jiangsu 210095, China.

Received: 5 July 2017 Accepted: 16 January 2018

Published online: 13 March 2018

\section{References}

1. Wu G, Bazer FW, Wallace JM, Spencer TE. Board-invited review: intrauterine growth retardation: implications for the animal sciences. J Anim Sci. 2006;84:2316-37.

2. Su G, Lund MS, Sorensen D. Selection for litter size at day five to improve litter size at weaning and piglet survival rate. J Anim Sci. 2007;85:1385-92.

3. Baserga M, Bertolotto C, Maclennan NK, Hsu JL, Pham T, Laksana GS, et al. Uteroplacental insufficiency decreases small intestine growth and alters apoptotic homeostasis in term intrauterine growth retarded rats. Early Hum Dev. 2004;79:93-105.

4. Wang $X$, Wu W, Lin G, Li D, Wu G, Wang J. Temporal proteomic analysis reveals continuous impairment of intestinal development in neonatal piglets with intrauterine growth restriction. J Proteome Res. 2009;9:924-35.

5. Garite TJ, Clark R, Thorp JA. Intrauterine growth restriction increases morbidity and mortality among premature neonates. Am J Obstet Gynecol. 2004:191:481-7.

6. Bauer E, Williams BA, Smidt H, Verstegen MW, Mosenthin R. Influence of the gastrointestinal microbiota on development of the immune system in young animals. Curr Issues Intest Microbiol. 2006;7:35-52.

7. Moughan PJ, Birtles MJ, Cranwell PD, Smith WC, Pedraza M. The piglet as a model animal for studying aspects of digestion and absorption in milk-fed human infants. In: Nutritional triggers for health and in disease. Basel: Karger Publishers; 1992. p. 40-113.

8. Bateup J, Dobbinson S, Munro K, Mc Connell MA, Tannock GW. Molecular analysis of the composition of Lactobacillus populations inhabiting the stomach and caecum of pigs. Microb Ecol Health Dis. 1998;10:95-102.

9. Inoue R, Tsukahara T, Nakanishi N, Ushida K. Development of the intestinal microbiota in the piglet. J Gen Appl Microbiol. 2005;51:257-65.

10. Konstantinov SR, Awati AA, Williams BA, Miller BG, Jones P, Stokes CR. Post-natal development of the porcine microbiota composition and activities. Environ Microbiol. 2006;8:1191-9.

11. Pieper R, Janczyk P, Zeyner A, Smidt H, Guiard V, Souffrant WB. Ecophysiology of the developing total bacterial and Lactobacillus communities in the terminal small intestine of weaning piglets. Microbial Ecol. 2008;56:474-83.

12. Hallstrom M, Eerola E, Vuento R, Janas M, Tammela O. Effects of mode of delivery and necrotising enterocolitis on the intestinal microflora in preterm infants. Eur J Clin Microbiol. 2004;23:463-70.

13. Noverr MC, Huffnagel GB. Does the microbiota regulate immune responses outside the gut? Trends Microbiol. 2004;12:562-8.
14. Penders J, Stobberingh EE, Thijs C, Adams H, Vink C, van Ree R, et al. Molecular fingerprinting of the intestinal microbiota of infants in whom atopic eczema was or was not developing. Clin Exp Allergy. 2006;36:1602-8.

15. Fanca-Berthon P, Hoebler C, Mouzet E, David A, Michel C. Intrauterine growth restriction not only modifies the cecocolonic microbiota in neonatal rats but also affects its activity in young adult rats. J Pediatr Gastroenterol Nutr. 2010;51:402-13.

16. Wang T, Huo Y, Shi F, Xu R, Hutz RJ. Effects of intrauterine growth retardation on development of the gastrointestinal tract in neonatal pigs. Biol Neonate. 2005;88:66-72.

17. D'Inca R, Kloareg M, Gras-Le Guen C, Le Huërou-Luron I. Intrauterine growth restriction modifies the developmental pattern of intestinal structure, transcriptomic profile, and bacterial colonization in neonatal pigs. J Nutr. 2010;140:925-31.

18. Fung $\mathrm{CM}$, White JR, Brown AS, Gong H, Weitkamp J, Frey MR, et al. Intrauterine growth restriction alters mouse intestinal architecture during development. PLoS One. 2016;11:e0146542.

19. Siggers RH, Siggers J, Thymann T, Boye M, Sangild PT. Nutritional modulation of the gut microbiota and immune system in preterm neonates susceptible to necrotizing enterocolitis. J Nutr Biochem. 2011;22:511-21.

20. Hooper LV, Wong MH, Thelin A, Hansson L, Falk PG, Gordon JI. Molecular analysis of commensal host-microbial relationships in the intestine. Science. 2001;291:881-4

21. Sudo N, Sawamura S, Tanaka K, Aiba Y, Kubo C, Koga Y. The requirement of intestinal bacterial Flora for the development of an IgE production system fully susceptible to oral tolerance induction. J Immunol. 1997;159:1739-45.

22. Guarner F, Malagelada JR. Gut flora in health and disease. Lancet. 2003;361:512-9.

23. Hong HA, Duc LH, Cutting SM. The use of bacterial spore formers as probiotics. FEMS Microbiol Rev. 2005;29:813-35.

24. Gaggia F, Mattarelli P, Biavati B. Probiotics and prebiotics in animal feeding for safe food production. Int J Food Microbiol. 2010;141(Suppl):15-28.

25. Novak KN, Davis E, Wehnes CA, Shields DR, Coalson JA, Smith AH, et al. Effect of supplementation with an electrolyte containing a Bacillus-based direct-fed microbial on immune development in dairy calves. Res Vet Sci. 2012;92:427-34.

26. Sun $P$, Wang JQ, Zhang HT. Effects of Bacillus subtilis natto on performance and immune function of preweaning calves. J Dairy Sci. 2010;93:5851-5.

27. Ji J, Hu S, Zheng M, Du W, Shang Q, Li W. Bacillus amyloliquefaciens SCO6 inhibits ETEC-induced pro-inflammatory responses by suppression of MAPK signaling pathways in IPEC-1 cells and diarrhea in weaned piglets. Livest Sci. 2013;158:206-14.

28. Li Y, Zhang H, Chen YP, Yang MX, Zhang LL, Lu ZX, et al. Bacillus amyloliquefaciens supplementation alleviates immunological stress and intestinal damage in lipopolysaccharide-challenged broilers. Anim Feed Sci Tech. 2015;208:119-31.

29. Zhang H, Li Y, Su W, Ying Z, Zhou L, Zhang L, et al. Resveratrol attenuates mitochondrial dysfunction in the liver of intrauterine growth retarded suckling piglets by improving mitochondrial biogenesis and redox status. Mol Nutr Food Res. 2016;5:1600653.

30. NRC. Nutrient requirements of swine. 11th ed. Washington: Natl. Acad. Press; 2012.

31. Brown DC, Maxwell CV, Erf GF, Davis ME, Singh S, Johnson ZB. The influence of different management systems and age on intestinal morphology, immune cell numbers and mucin production from goblet cells in post-weaning pigs. Vet Immunol Immunopathol. 2006;111:187-98.

32. Scholzen T, Gerdes J. The Ki-67 protein: from the known and the unknown. J Cell Physiol. 2000;182:311-22.

33. Fierer $\mathrm{N}$, Jackson JA, Vilgalys R, Jackson RB. Assessment of soil microbial community structure by use of taxon-specific quantitative PCR assays. Appl Environ Microbiol. 2005;71:4117-20.

34. Rinttila T, Kassinen A, Malinen E, Krogius L, Palva A. Development of an extensive set of 165 rDNA-targeted primers for quantification of pathogenic and indigenous bacteria in faecal samples by real-time PCR. J Appl Microbiol. 2004;97:1166-77.

35. Jensen SR, Fink LN, Struve C, Sternberg C, Andersen JB, Brynskov J, et al. Quantification of specific E. coli in gut mucosa from Crohn's disease patients. J Microbiol Methods. 2011;86:111-4.

36. Han GQ, Xiang ZT, Yu B, Chen DW, Qi HW, Mao XB, et al. Effects of different starch sources on Bacillus spp. in intestinal tract and expression of intestinal development related genes of weanling piglets. Mol Biol Rep. 2012;39: 1869-76. 
37. Matsuki T, Watanabe K, Fujimoto J, Takada T, Tanaka R. Use of $16 \mathrm{~S}$ rRNA gene-targeted group-specific primers for real-time PCR analysis of predominant bacteria in human feces. Appl Environ Microb. 2004;70:7220-8

38. Xu J, Xu C, Chen X, Cai X, Yang S, Sheng Y, et al. Regulation of an antioxidant blend on intestinal redox status and major microbiota in early weaned piglets. Nutrition. 2014;30:584-9.

39. Zhang H, Su W, Ying Z, Chen Y, Zhou L, Li Y, et al. N-acetylcysteine attenuates intrauterine growth retardation-induced hepatic damage in suckling piglets by improving glutathione synthesis and cellular homeostasis. Eur J Nutr. 2016; https://doi.org/10.1007/s00394-016-1322-x.

40. Livak KJ, Schmittgen TD. Analysis of relative gene expression data using real-time quantitative PCR and the 2(-Delta Delta C(T)) method. Methods. 2001;25:402-8

41. Shanklin DR, Cooke RJ. Effects of intrauterine growth on intestinal length in the human fetus. Biol Neonate. 1993;64:76-81.

42. Xu RJ, Mellor DJ, Birtles MJ, Reynolds GW, Simpson HV. Impact of intrauterine growth retardation on the gastrointestinal tract and the pancreas in newborn pigs. J Pediatr Gastroenterol Nutr. 1994;18:231-40.

43. Ramachandran A, Madesh M, Balasubramanian KA. Apoptosis in the intestinal epithelium: its relevance in normal and pathophysiological conditions. J Gastroenterol Hepatol. 2000;15:109-20.

44. Lane RH, Ramirez RJ, Tsirka AE, Kloesz JL, McLaughlin MK, Gruetzmacher EM, et al. Uteroplacental insufficiency lowers the threshold towards hypoxia-induced cerebral apoptosis in growth-retarded fetal rats. Brain Res. 2001;895:186-93.

45. Pham TD, MacLennan NK, Chiu CT, Laksana GS, Hsu JL, Lane RH. Uteroplacental insufficiency increases apoptosis and alters p53 gene methylation in the full-term IUGR rat kidney. Am J Physiol Regul Integ Comp Physiol. 2003;285:R962-70.

46. Ferenc K, Pietrzak P, Godlewski MM, Piwowarski J, Kiliańczyk R, Guilloteau P, et al. Intrauterine growth retarded piglet as a model for humans-studies on the perinatal development of the gut structure and function. Reprod Biol. 2014;14:51-60

47. Han F, Hu L, Xuan Y, Ding X, Luo Y, Bai S, et al. Effects of high nutrient intake on the growth performance, intestinal morphology and immune function of neonatal intra-uterine growth-retarded pigs. Br J Nutr. 2013;110:1819-27.

48. McCracken BA, Gaskins HR, Ruwe-Kaiser PJ, Klasing KC, Jewell DE. Diet-dependent and diet-independent metabolic responses underlie growth stasis of pigs at weaning. J Nutr. 1995;125:2838-45.

49. Pié $S$, Lallès JP, Blazy F, Laffitte J, Sève B, Oswald IP. Weaning is associated with an upregulation of expression of inflammatory cytokines in the intestine of piglets. J Nutr. 2004;134:641-7.

50. Kim YS, Ho SB. Intestinal goblet cells and mucins in health and disease: recent insights and progress. Curr Gastroenterol Rep. 2010;12:319-30.

51. Dharmani P, Srivastava V, Kissoon-Singh V, Chadee K. Role of intestinal mucins in innate host defense mechanisms against pathogens. J Innate Immun. 2009;1:123-35.

52. Einerhand AW, Renes IB, Makkink MK, van der Sluis M, Büller HA, Dekker J. Role of mucins in inflammatory bowel disease: important lessons from experimental models. Eur J Gastroenterol Hepatol. 2002;14:757-65.

53. Sartor RB. Cytokines in intestinal inflammation: pathophysiological and clinical consideration. Gastroenterology. 1994;106:533-9.

54. Dunsford BR, Haensly WE, Knabe DA. Effects of diet on acidic and neutral goblet cell populations in the small intestine of early weaned pigs. Am J Vet Res. 1991:52:1743-6.

55. Fanca-Berthon P, Michel C, Pagniez A, Rival M, Van Seuningen I, Darmaun D, et al. Intrauterine growth restriction alters postnatal colonic barrier maturation in rats. Pediatr Res. 2009;66:47-52.

56. Pelaseyed T, Bergstrom JH, Gustafsson JK, Ermund A, Birchenough GMH, Schütte $A$, et al. The mucus and mucins of the goblet cells and enterocytes provide the first defense line of the gastrointestinal tract and interact with the immune system. Immunol Rev. 2014;260:8-20.

57. Dong L, Zhong $X$, Ahmad H, Li W, Wang YX, Zhang LL, et al. Intrauterine growth restriction impairs small intestinal mucosal immunity in neonatal piglets. J Histochem Cytochem. 2014;62:510-8.

58. Nicholls SJ, Hazen SL. Myeloperoxidase and cardiovascular disease. Arterioscler Thromb Vasc Biol. 2005;25:1102-11.

59. Brzek $\mathrm{P}$, Konarzewski M. Relationship between avian growth rate and immune response depends on food availability. J Exp Biol. 2007;210:2361-7.

60. Yan F, Polk DB. Probiotics: progress toward novel therapies for intestinal diseases. Curr Opin Gastroenterol. 2010;26:95.
61. Hairul Islam VI, Babu NP, Pnadikumar P, Ignacimuthu S. Isolation and characterization of putative probiotic bacteria strain, Bacillus amyloliquefaciens, from north east Himalayan soil based on in vitro and in vivo functional properties. Probiotics Antimicrob Proteins. 2011;3:175-85.

62. Li JJ, Guo YL, Yang YJ. Enhancing anti-inflammatory cytokine IL-10 may be beneficial for acute coronary syndrome. Med Hypotheses. 2005:65:103-6.

63. Eun BS, Lee YG, Kim BH, Shen T, Lee SY, Park HJ, et al. Surfactin blocks NO production in lipopolysaccharide-activated macrophages by inhibiting NF-kappaB activation. J Microbiol Biotechnol. 2008;18:1984-9.

64. Park SY, Kim JH, Sang JL, Kim YH. Involvement of PKA and HO-1 signaling in anti-inflammatory effects of surfactin in BV-2 microglial cells. Toxicol Appl Pharm. 2013;268:68-78.

65. Sharma S, Yang B, Xi X, Grotta JC, Aronowski J, Savitz SI. IL-10 directly protects cortical neurons by activating PI-3 kinase and STAT-3 pathways. Brain Res. 2011:1373:189-94.

66. Gao Z, Zhao X, Yang T, Shan J, Shang L, Mai H, et al. Immunomodulation therapy of diabetes by oral administration of a surfactin lipopeptide in NOD mice. Vaccine. 2014;32:6812-9.

67. Cai L, Indrakumar $\mathrm{S}$, Kiarie $\mathrm{E}$, Kim $\mathrm{H}$. Effects of a multi-strain species-based direct-fed microbial on growth performance, nutrient digestibility, blood profile, and gut health in nursery pigs fed corn-soybean meal-based diets. J Anim Sci. 2015;93:4336-42.

68. Hu L, Peng X, Chen H, Yan C, Liu Y, Xu Q, et al. Effects of intrauterine growth retardation and Bacillus subtilis PB6 supplementation on growth performance, intestinal development and immune function of piglets during the suckling period. Eur J Nutr. 2016; https://doi.org/10.1007/s00394-016-1223-z.

69. Fujiya M, Musch MW, Nakagawa Y, Alverdy J, Kohgo Y, Schneewind O, et al. The Bacillus subtilis quorum-sensing molecule CSF contributes to intestinal homeostasis via OCTN2, a host cell membrane transporter. Cell Host Microbe. 2007:1:299-308.

70. Caballero-Franco C, Keller K, De Simone C, Chadee K. The VSL\#3 probiotic formula induces mucin gene expression and secretion in colonic epithelial cells. Am J Physiol Gastrointest Liver Physiol. 2007;292:G315-22.

71. Khailova L, Baird CH, Rush AA, Barnes C, Wischmeyer PE. Lactobacillus rhamnosus GG treatment improves intestinal permeability and modulates inflammatory response and homeostasis of spleen and colon in experimental model of Pseudomonas aeruginosa pneumonia. Clin Nutr. 2016; https://doi.org/ 10.1016/j.clnu.2016.09.025

72. Aliakbarpour HR, Chamani M, Rahimi G, Sadeghi AA, Qujeq D. The Bacillus subtilis and lactic acid bacteria probiotics influences intestinal mucin gene expression, histomorphology and growth performance in broilers. Asian-Australas J Anim Sci. 2012;25:1285-93.

73. Gadde UD, Oh S, Lee Y, Davis E, Zimmerman N, Rehberger T, et al. Dietary Bacillus subtilis-based direct-fed microbials alleviate LPS-induced intestinal immunological stress and improve intestinal barrier gene expression in commercial broiler chickens. Res Vet Sci. 2017;114:236-43.

74. Selim KM, Reda RM. Improvement of immunity and disease resistance in the Nile tilapia, Oreochromis niloticus, by dietary supplementation with Bacillus amyloliquefaciens. Fish Shellfish Immunol. 2015:44:496-503.

75. Mashimo H, Wu DC, Podolsky DK, Fishman MC. Impaired defense of intestinal mucosa in mice lacking intestinal trefoil factor. Science. 1996;274:262-5

76. Deplancke B, Gaskins HR. Microbial modulation of innate defense: goblet cells and the intestinal mucus layer. Am J Clin Nutr. 2001;73(Suppl):1131-41.

77. Ahmed ST, Islam MM, Mun HS, Sim HJ, Kim YJ, Yang CJ. Effects of Bacillus amyloliquefaciens as a probiotic strain on growth performance, cecal microflora, and fecal noxious gas emissions of broiler chickens. Poult Sci. 2014:93:1-9.

78. Song J, Xiao K, Ke YL, Jiao LF, Hu CH, Diao QY, et al. Effect of a probiotic mixture on intestinal microflora, morphology, and barrier integrity of broilers subjected to heat stress. Poult Sci. 2014;93:581-8.

79. Fang CJ, Lu ZX, Sun $\sqcup$. Optimization of fermentation technology for lipopeptides producing bacteria Bacillus amyloliquefaciens ES-2-4. Sci Agric Sin. 2008:41:533-9.

80. Wang Y, Zhu X, Bie X, Lu F, Zhang C, Yao S, et al. Preparation of microcapsules containing antimicrobial lipopeptide from Bacillus amyloliquefaciens ES-2 by spray drying. LWT-Food Sci Technol. 2014;56:502-7.

81. EFSA. Scientific opinion of the panel on additives and products or substances used in animal feed (FEEDAP) on a request from the European Commission on the safety and efficacy of Ecobiol ${ }^{\circledast}$ (Bacillus amyloliquefaciens) as feed additive for chickens for fattening. EFSA J. 2008;773:1-13.

82. Ulyanova $\mathrm{V}$, Vershinina $\mathrm{V}$, llinskaya O. Barnase and binase: twins with distinct fates. FEBS J. 2011;278:3633-43. 
83. Herzner AM, Dischinger J, Szekat C, Josten M, Schmitz S, Yakeleba A, et al. Expression of the lantibiotic mersacidin in Bacillus amyloliquefaciens FZB42. PLoS One. 2011;6:e22389.

84. Chen H, Mao X, He J, Yu B, Huang Z, Yu J, et al. Dietary fibre affects intestinal mucosal barrier function and regulates intestinal bacteria in weaning piglets. Br J Nutr. 2013;110:1837-48.

Submit your next manuscript to BioMed Central and we will help you at every step:

- We accept pre-submission inquiries

- Our selector tool helps you to find the most relevant journal

- We provide round the clock customer support

- Convenient online submission

- Thorough peer review

- Inclusion in PubMed and all major indexing services

- Maximum visibility for your research

Submit your manuscript at www.biomedcentral.com/submit 